\title{
Myocardial revascularization in patient with situs inversus totalis: case report
}

\author{
Revascularização do miocárdio em paciente com situs inversus totalis: relato de caso
}

George Ronald SONCINI DA ROSA*, Viviane Guzzo LEMKE*, Walmor LEMKE*, João MADEIRA NETO*, Américo Álvaro Farinha MARTINS*, Luiz Fernando KUBRUSLY*

RBCCV 44205-611

\section{Abstract}

This is a report of an unusual case of a patient, with dextrocardia and a "situs inversus totalis". She presented angina pectoris during an ECG stress test. The coronary arteriography revealed severe obstruction in the main left coronary artery. The patient underwent coronary artery bypass grafting surgery. We did not find a similar case in the national medical literature. The myocardial revascularization performed utilizing the right mammary artery for anterior descending artery and saphenous vein grafts for first diagonal branch and first marginal branch.

Descriptors: Dextrocardia, surgery. Situs inversus. Myocardial revascularization.

\section{INTRODUCTION}

Dextrocardia associated with situs inversus is a rare condition with an incidence of 1:10,000 of the population $[1,2]$.

The association of situs inversus totalis and coronary atherosclerosis has the same incidence in the population. There are few published reports of myocardial revascularization in patients with this anomaly [3-11].

\section{Resumo}

Este é um relato de caso infrequiente de uma paciente com dextrocardia associada a "situs inversus totalis" que apresentou dor precordial típica ao teste ergométrico. A cineangiocoronariografia revelou lesão coronariana crítica de tronco de artéria coronária esquerda. Foi levada à operação de revascularização do miocárdio. Não foram encontrados relatos de casos semelhantes na literatura médica nacional. A revascularização do miocárdio foi realizada com a artéria mamária interna direita (torácica interna direita) para artéria descendente anterior e enxerto de veia safena para o primeiro ramo diagonal e primeiro ramo marginal.

Descritores: Dextrocardia, cirurgia. Situs inversus. Revascularização miocárdica.

\section{CASEREPORT}

A 53-year-old female Caucasian patient suffering from type II diabetes, dyslipidemia and hypothyroidism is reported who also had situs inversus totalis and a family history of heart disease. Stable angina was evidenced at the slightest effort. Conventional electrocardiography (ECG) evidenced typical dextrocardia without ischemic alterations (Figure 1). Thoracic radiography was normal except for the dextrocardia (Figure 2).

Work performed in the Hospital Santa Cruz de Curitiba. Paraná, PR, Brazil.

*Hospital Santa Cruz de Curitiba.

Correspondence address: George R. Soncini da Rosa. Av. Silva

Jardim 2939, apto 111. Curitiba, PR, Brazil. CEP: 80240-020.

Tel: (41) 342-4505. Mobile (41) 9979-2789. Fax (41) 342-4505.

E-mail: soncini@bsi.com.br 

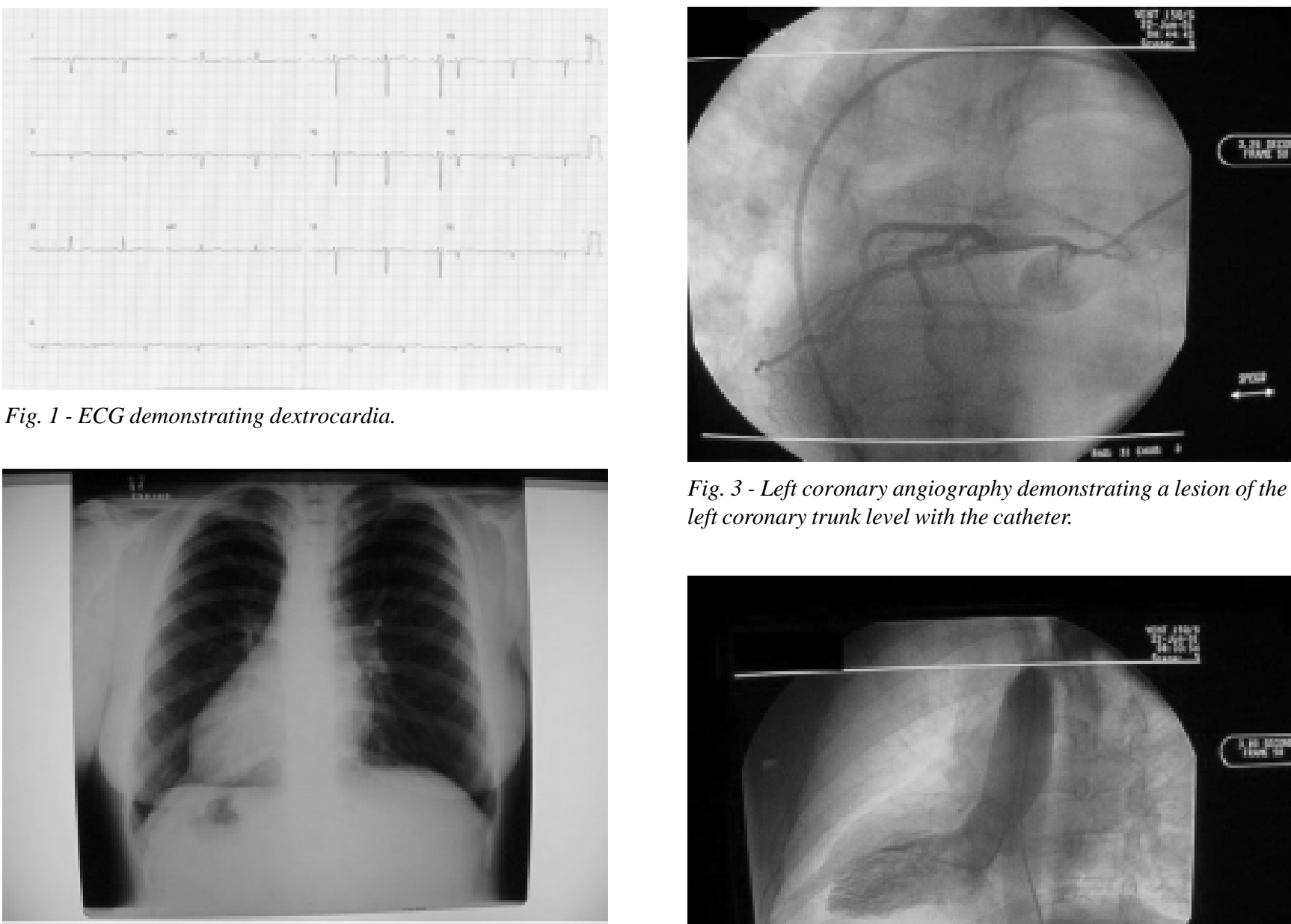

Fig. 2 - Thoracic radiography revealing dextrocardia (cardiac apex to the right) with the presence of gastric bubble to the right.

A ECG stress test demonstrated a positive response for myocardial ischemia. Following this a coronary cineangiography was performed which showed a $70 \%$ obstructive lesion of the left coronary artery branch trunk (Figure 3). During the examination the patient presented with intense precordial pain with a significant alteration of the ECG, with supra-irregularity of the ST segment of the anterolateral wall. The left ventriculography was normal (Figure 4). She was taken to the intensive care unit and initiated treatment with endovenous issorbide monohydrate and endovenous 30,000U heparin over 24 hours. After 24 hours of observation, without alterations of the cardiac enzymes, the myocardial revascularization surgery was initiated. On 27th June 2001, the patient was submitted to a surgical procedure of the myocardium. The right internal mammary artery was anastomosed in the anterior descending artery and a great saphenous vein graft was utilized for the first marginal branch of the circumflex artery and the first oblique branch of the anterior descending artery (Figure 5). A cardiopulmonary bypass was performed at $33{ }^{\circ} \mathrm{C}$, with a total ischemia time of 55 minutes and perfusion over 86
Fig. 3 - Left coronary angiography demonstrating a lesion of the left coronary trunk level with the catheter.

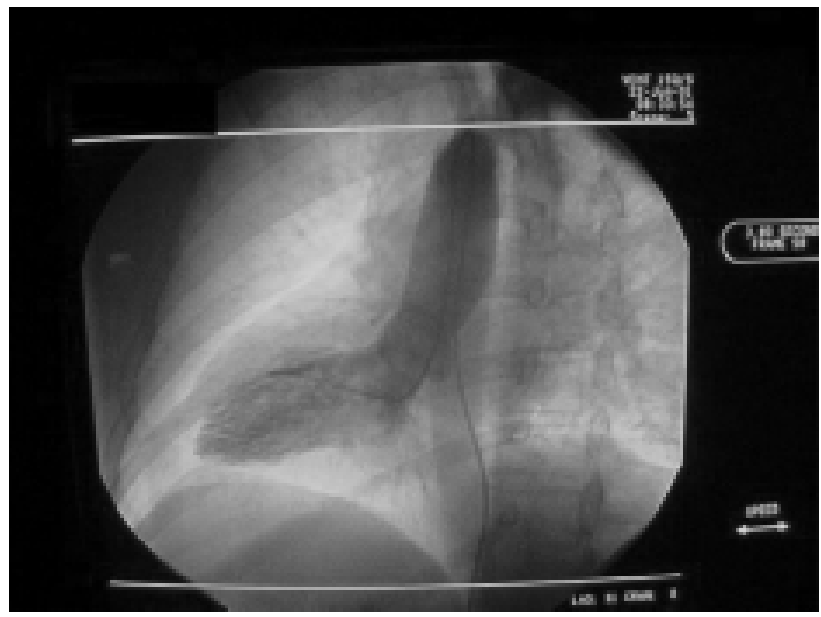

Fig. 4 - A normal left ventriculography except for the dextrocardia.

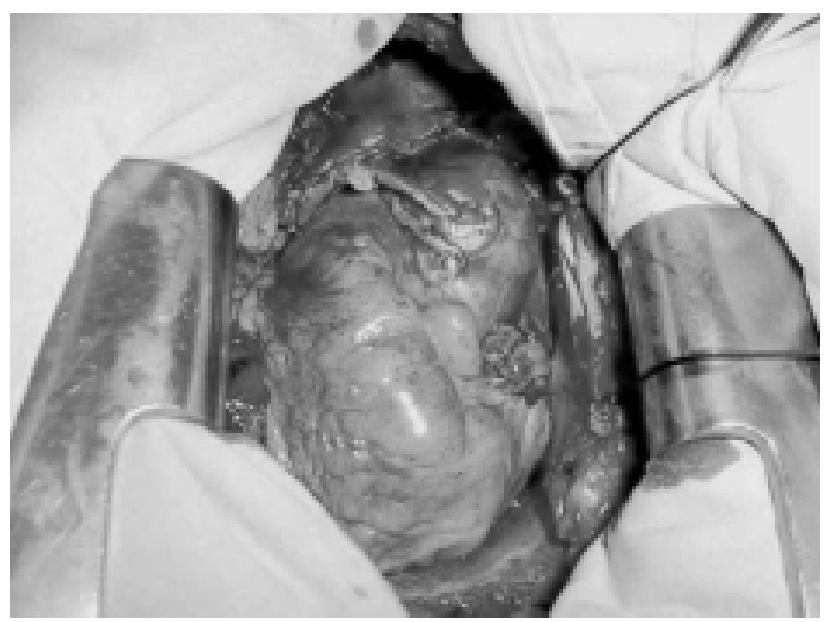

Fig. 5 - Final surgical result after coronary anastomosis. Note the dextrocardia. 
minutes. The post-operative period was uneventful and she was released from hospital on the 8th day after surgery. After one year, the patient was asymptomatic from the cardiological point of view and without ECG alterations.

\section{COMMENTS}

Dextrocardia associated with situs inversus totalis is rare. It occurs in 1:10,000 people and it is uncommonly associated with other cardiac lesions. The incidence of acquired atherosclerosis of the coronary arteries in these patients has not been well established, but there is an estimate that it is similar to that in the general population. The first person to report situs inversus was Hieronymus Fabricius in 1606 [12].

According to our investigation of publications, this is the sixth reported case in the world, and the first in Brazil, in which the right internal thoracic artery and the left great saphenous vein were used as grafts for myocardial revascularization. The only internationally published report of a heart with situs inversus by Brazilian authors was in 1988, written by ABENSUR et al. [4] who utilized only the right internal thoracic artery for grafting. The surgical procedure in these patients presents a particularity: the surgeon must position himself on the left of the surgical table which initially is uncomfortable but this naturally passes as the surgeon adapts to the new position.

\section{ACKNOWLEDGEMENTS}

We would like to express our thanks the Professor Dr. Iseu Affonso da Costa for his assistance in the revision of this article.
4. Abensur H, Ramires JA, Dallan LA, Jatene A. Right mammarycoronary anastomosis in a patient with situs inversus. Chest 1988; 94: 886-7.

5. Yamaguchi T, Kikuchi S, Doi H, Watanabe A, Ebuoka M. Coronary artery bypass in dextrocardia with situs inversus totalis: a case report. Nippon Kyobu Geka Gakkai Zasshi 1990; 38: 1538-42.

6. Mesa JM, Aroca A, Frutos A, Centeno J, Silvestre J, Baset F. Situs inversus and myocardial revascularization: case report. J Cardiovasc Surg (Torino) 1995; 36: 571-2.

7. Nomoto T, Ueda Y, Ogino H, Sugita T, Morioka K, Matsubayashi K. Emergent coronary artery bypass grafting in a patient with mirror-image dextrocardia. Kyobu Geka 1997; 50: 785-8.

8. Seddio F, Colagrande L, Pellegrino A, De Paulis R, Bassano C, Chiariello L. Myocardial revascularization in dextrocardia with situs inversus. G Ital Cardiol 1999; 29: 1222-6.

9. Wong PS, Chong CL. Multiple coronary artery bypass grafting in dextrocardia: case report. Med J Malaysia 1999; 54: 514-6.

10. Grey DP, Cooley DA. Dextrocardia with situs inversus totalis: cardiovascular surgery in three patients with concomitant coronary artery disease. Cardiovasc Dis Bull Texas Heart Inst 1981; 8: 527-30.

11. Irvin RG, Ballenger JF. Coronary artery bypass surgery in a patient with situs inversus. Chest 1982; 81: 380-1.

12. Cleveland M. Situs inversus viscerum: anatomic study. Arch Surg 1926; 13: 343.

\section{BIBLIOGRAPHIC REFERENCES}

1. Rosenberg HN, Rosenberg IN. Simultaneous association of situs inversus, coronary heart disease and hiatus hernia. Ann Intern Med 1949; 30: 851-9.

2. Torgersen J. Genetic factors in visceral asymmetry and in the development and pathologic changes of lungs, heart and abdominal organs. Arch Pathol 1949; 47:566-93.

3. Moreno-Cabral RJ, Daily PO. Coronary bypass in dextrocardia. Chest 1984; 85: 714. 